\title{
Chemical Control of Morning Glory Species in Sugarcane HaRVested In THE DRY AND SEMI-WeT SEASONS ${ }^{1}$
}

\author{
Controle Químico de Espécies de Corda-de-Viola em Áreas de Cana Soca Crua Colhida nas \\ Épocas Seca e Semiúmida
}

CORREIA, N.M. ${ }^{2}$

\begin{abstract}
The control of morning glory (Ipomoea spp. and Merremia aegyptia) was evaluated in five commercial sugarcane-production fields receiving applications of the herbicides sulfentrazone $\left(0.9 \mathrm{~kg} \mathrm{ha}^{-1}\right)$, amicarbazone $\left(1.4 \mathrm{~kg} \mathrm{ha}^{-1}\right)$, imazapic $\left(0.147 \mathrm{~kg} \mathrm{ha}^{-1}\right)$, and hexazinone + tebuthiuron $\left(0.325+0.75 \mathrm{~kg} \mathrm{ha}^{-1}\right)$ applied pre-emergence in either the dry season (July and August) or in the semi-wet season (early October); mesotrione alone $\left(0.192 \mathrm{~kg} \mathrm{ha}^{-1}\right)$ or in combination $\left(0.12 \mathrm{~kg} \mathrm{ha}^{-1}\right)$ with atrazine $\left(1.5 \mathrm{~kg} \mathrm{ha}^{-1}\right)$ or diuron + hexazinone $(0.491+$ $0.139 \mathrm{~kg} \mathrm{ha}^{-1}$ ) applied post-emergence in the wet season (November), and the phytointoxication of the chemical treatments for sugarcane. Five species of morning glory (Ipomoea hederifolia, Ipomoea nil, Ipomoea quamoclit, Ipomoea triloba and Merremia aegyptia) were assessed in the experiments. The applications during the dry, semi-wet, and wet seasons resulted in similar levels of control of I. hederifolia, I. nil, I. quamoclit, and I. triloba. The herbicides imazapic and mesotrione alone resulted in lower levels of control of $M$. aegyptia. Imazapic and the combination of mesotrione + (diuron + hexazinone) caused greater visible phytotoxicity to sugarcane than other herbicides applied during the dry and semi-wet seasons. However, the greatest loss of production was attributed to amicarbazone.
\end{abstract}

Keywords: herbicide, Ipomoea spp., Merremia aegyptia, pre-emergence, post-emergence, Saccharum spp.

RESUMO - Cinco experimentos foram instalados em áreas de produção comercial de cana-de-açúcar para estudar o controle de corda-de-viola (Ipomoea spp. e Merremia aegyptia) pelos herbicidas

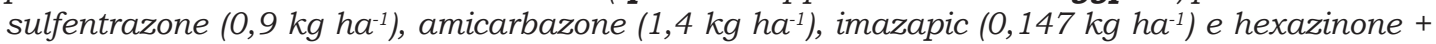

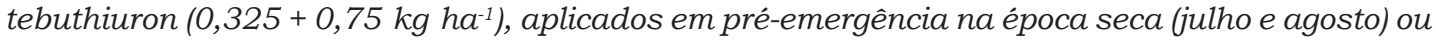
semiúmida (início de outubro); mesotrione isolado (0,192 $\left.\mathrm{kg} \mathrm{ha}^{-1}\right)$ e em mistura (0,12 $\left.\mathrm{kg} \mathrm{ha}^{-1}\right) \mathrm{com}$ atrazine $\left(1,5 \mathrm{~kg} \mathrm{ha}^{-1}\right)$ ou diuron + hexazinone $\left(0,491+0,139 \mathrm{~kg} \mathrm{ha}^{-1}\right)$, aplicados em pós-emergência na época úmida (novembro); e a seletividade dos tratamentos químicos para cana-de-açúcar. Cinco espécies de corda-de-viola (Ipomoea hederifolia, Ipomoea nil, Ipomoea quamoclit, Ipomoea triloba e Merremia aegyptia) foram avaliadas nos experimentos. Tanto os tratamentos das épocas seca e semiúmida quanto os de úmida resultaram em controle similar de I. hederifolia, I. nil, I. quamoclit e I. triloba. Os herbicidas imazapic e mesotrione isolado promoveram menor porcentagem de controle de M. aegyptia. O imazapic e a mistura mesotrione + (diuron + hexazinone) ocasionaram maior fitointoxicação visual à cana-de-açúcar, comparados aos outros herbicidas de seca e semiúmida; contudo, a maior perda de produção foi promovida pelo amicarbazone.

Palavras-chave: herbicidas, Ipomoea spp., Merremia aegyptia, pré-emergência, pós-emergência, Saccharum spp.

\section{INTRODUCTION}

Brazil is the largest producer of sugarcane, contributing with more than $48 \%$ of the total production of sugar in the world (FAO, 2016).
In 2015, sugarcane was cultivated in over 9.91 million hectares, with production of about 755 million tons in Brazil (IBGE, 2016). In the Southeast and Midwest regions of Brazil, the sugarcane harvest begins in April/May,

\footnotetext{
Recebido para publicação em 5.6.2015 e aprovado em 28.10.2015.
}

2 Embrapa, Brasília-DF, Brazil, <nubia.correia@embrapa.br>. 
extending until November/December of the agricultural year. After cutting, the cultural practices required for budding and plant growth are performed, including weed management. In drier times of the year (June, July and August), the application of herbicides can be made in pre-emergence, post-harvest or postemergence when soil moisture is restored. However, for use in the dry season, the herbicides must show high water solubility, low or moderate adsorption to the soil, and low or no volatilization and photodegradation. Thus, even under low moisture soil condition, part of the product will be desorbed to the solution and available for absorption by the radicle and/or seedling cauliculos.

On the other hand, adapted to herbicide applications in the dry season, the producers have faced some adversity in weed control in recent years. First, there is the straw, originating from mechanical harvesting with no sugarcane burning, which may compromise the ability of the residual herbicide to reach the ground. Depending on the physical and chemical properties of the herbicide, such as solubility, vapor pressure and polarity, the straw will have more or less influence on its effectiveness (Rodrigues, 1993; Selim et al., 2012). The amount and period in which rainfall or irrigation occur after application, in addition to the degree of decomposition or the age of the plant residues, can also greatly influence the adsorption of the herbicide straw (Mersie, 2006; Selim \& Naquin, 2011; Correia et al., 2013; Giori et al., 2014). The herbicide will be exposed to losses due to photodegradation and volatilization even at adsorption plant residues while its removal from the straw to the soil does not occur.

Over the years, increased infestation of species of climbing plants, such Ipomoea and Merremia (popularly known as morning glory), as was noticed in the sugarcane areas. Possibly, the maintenance of sugarcane straw on the soil surface creates an environment more favorable for seed germination and for such plants development due to lower daily temperature range, greater conservation of soil moisture and chemical improvement and soil physics. Furthermore, with the mechanized harvesting of sugarcane, the spread of morning glory seeds for the harvester, either in the same area or from one area to another, was facilitated. If they are not controlled, these species can compete with sugarcane, interfere with mechanical harvesting operation and reduce productivity. It has been reported that the competition of Ipomoea spp. can reduce the production of sugarcane stalks from 27\% to 36\% (Jones \& Griffin, 2009; Bhullar et al., 2012.). Thus, handling morning glory in the cane fields is a serious challenge for producers and technicians (Bhullar et al., 2012).

Assuming that the control of morning glory by herbicides sprayed in the wet season is effective and safe for sugarcane and similar to the application of herbicides in dry and semiwet seasons, this study was conducted. The objective was to evaluate the control of morning glory (Ipomoea spp. and Merremia aegyptia) by herbicides sprayed pre-emergence during the dry and semi-wet seasons, compared to herbicides applied post-emergence of the plants in the wet season; also study the selectivity of chemical treatments for sugarcane.

\section{MATERIAL AND METHODS}

Five experiments were conducted in areas of commercial production of sugarcane in the Catanduva area, SP - Brazil, from July to October 2012, and conducted until July 2013.

Each experiment was carried out in accordance with the following information.

The experimental design was randomized blocks, with 11 treatments and four replications. The herbicides sulfentrazone (0.9 kg ha-1), amicarbazone $\left(1.4 \mathrm{~kg} \mathrm{ha}^{-1}\right)$, imazapic $\left(0.147 \mathrm{~kg} \mathrm{ha}^{-1}\right)$ and hexazinone + tebuthiuron $\left(0.325+0.75 \mathrm{~kg} \mathrm{ha}^{-1}\right)$, applied preemergence after the sugarcane harvest in the dry season (July and August) or semi-wet season (early October); and mesotrione alone $\left(0.192 \mathrm{~kg} \mathrm{ha}^{-1}\right)$ or in combination $\left(0.12 \mathrm{~kg} \mathrm{ha}^{-1}\right)$ with atrazine $\left(1.5 \mathrm{~kg} \mathrm{ha}^{-1}\right)$ or diuron + hexazinone $\left(0.491+0.139 \mathrm{~kg} \mathrm{ha}^{-1}\right)$, applied post-emergence of sugarcane and weeds in the wet season (November) were evaluated. In addition, four untreated controls were kept (control 1- kept free of weeds until the herbicide application in the wet season; control 2- kept free of weeds from the application of herbicides in the wet season; control 3- kept free of weeds from sprouting 
until harvest, and control 4- kept with weeds from sprouting until harvest). The treatments in the experiments are shown in Table 1.

The areas were chosen based on history of high morning glory infestation (genera Ipomoea and Merremia) and straw maintenance on the soil. The sugarcane, in all experiments, was mechanically harvested with no previous plant burning and plant waste were kept on the ground, in the amount of 7.2 to $16.1 \mathrm{t} \mathrm{ha}^{-1}$. Table 2 shows the description of the five experimental areas, including cane varieties evaluated.

Each plot was $4.5 \mathrm{~m}$ wide (three rows of cane) and $14.0 \mathrm{~m}$ long, totaling $63.0 \mathrm{~m}^{2}$. Herbicide application and controls manual handling (1,2 and 3$)$ were made in an area of $36.0 \mathrm{~m}^{2}(3.0 \mathrm{~m} \times 12.0 \mathrm{~m})$. The rest of the area served as lateral and background control.
During the dry and semi-wet seasons, herbicides were sprayed in total area, with the assistance of knapsack sprayer at constant pressure (kept through $\mathrm{CO}_{2}$ compressed) of $4.0 \mathrm{kgf} \mathrm{cm}^{-2}$, equipped with six flat spray nozzles bar TTI 110015 , spaced $0.5 \mathrm{~m}$, with syrup consumption equivalent to $200 \mathrm{~L} \mathrm{ha}^{-1}$. In the wet season, due to the size of the cane, the spray was directed, located between the lines of culture, seeking to reach only the weeds without blockage from the sugarcane plants. Thus, a knapsack sprayer was used at constant pressure (maintained by compressed $\mathrm{CO}_{2}$ ) of $4.0 \mathrm{kgf} \mathrm{cm}^{-2}$, equipped with two flat spray nozzles bar TT 11002 , spaced $0.75 \mathrm{~m}$, with spray volume equivalent to $200 \mathrm{~L} \mathrm{ha}^{-1}$.

The date, time, soil moisture and weather conditions at the time of herbicides application in each experiment concluded, besides the

Table 1 - Description of the treatments studied in the experiments

\begin{tabular}{|c|c|c|c|c|c|}
\hline \multirow[b]{2}{*}{ Id. } & \multicolumn{2}{|c|}{ Herbicides/controls } & \multicolumn{2}{|c|}{ Dosages } & \multirow[b]{2}{*}{ Period } \\
\hline & Commercial product & Active ingredient & $\begin{array}{c}\text { p.c. } \\
\left(\mathrm{kg} \text { or } \mathrm{L} \mathrm{ha}{ }^{-1}\right)\end{array}$ & $\begin{array}{c}\text { i.a. } \\
\left(\mathrm{kg} \mathrm{ha}^{-1}\right)\end{array}$ & \\
\hline 1 & Boral & Sulfentrazone & 1.8 & 0.9 & \multirow{4}{*}{ Dry/Semi-wet (PRE) } \\
\hline 2 & Dinamic & Amicarbazone & 2.0 & 1.4 & \\
\hline 3 & Plateau & Imazapic & 0.21 & 0.147 & \\
\hline 4 & $\begin{array}{l}\text { Hexazinona Nortox } \\
\text { Combine }\end{array}$ & $\begin{array}{l}\text { Hexazinone } \\
\text { Tebuthiuron }\end{array}$ & $\begin{array}{l}1.3 \\
1.5\end{array}$ & $\begin{array}{l}0.325 \\
0.75\end{array}$ & \\
\hline 5 & Callisto $^{\underline{1}}$ & Mesotrione & 0.4 & 0.192 & \multirow{3}{*}{ Wet (POST) } \\
\hline 6 & $\begin{array}{l}\text { Callisto } \\
\text { Gesaprim }\end{array}$ & $\begin{array}{l}\text { Mesotrione } \\
\text { Atrazine }\end{array}$ & $\begin{array}{l}0.25 \\
3.0 \\
\end{array}$ & $\begin{array}{l}0.12 \\
1.5 \\
\end{array}$ & \\
\hline 7 & $\begin{array}{l}\text { Callisto } \\
\text { Velpar }\end{array}$ & $\begin{array}{l}\text { Mesotrione } \\
\text { Diuron } \\
\text { Hexazinone }\end{array}$ & $\begin{array}{l}0.25 \\
0.75\end{array}$ & $\begin{array}{l}0.12 \\
0.491 \\
0.139 \\
\end{array}$ & \\
\hline 8 & Control 1 & \multicolumn{4}{|c|}{ Kept free of weeds until the herbicide application in the wet season } \\
\hline 9 & Control 2 & \multicolumn{4}{|c|}{ Kept free of weeds from the application of herbicides in the wet season } \\
\hline 10 & Control 3 & \multicolumn{4}{|c|}{ Kept free of weeds throughout the cycle (sprouting-harvest). } \\
\hline 11 & Control 4 & \multicolumn{4}{|c|}{ Kept with weeds throughout the cycle (sprouting-harvest). } \\
\hline
\end{tabular}

${ }^{1 /}$ All syrup of Callisto were added with mineral oil at $0.5 \% \mathrm{v} \mathrm{v}^{-1}$.

Table 2 - Description of the experimental areas used in each experiment

\begin{tabular}{|c|c|c|c|c|c|c|c|c|}
\hline \multirow{2}{*}{ Exp. } & \multirow{2}{*}{ County } & \multicolumn{2}{|c|}{ Date of application } & \multirow{2}{*}{$\begin{array}{l}\text { Soil texture } \\
\text { classification }\end{array}$} & \multirow{2}{*}{ Variety } & \multicolumn{2}{|r|}{ Date } & \multirow{2}{*}{$\begin{array}{l}\text { Straw } \\
\left(\mathrm{t} \mathrm{ha}^{-1}\right)\end{array}$} \\
\hline & & PRE & POST & & & Plantation & Latest cut & \\
\hline 1 & Itápolis & $07 / 11 / 12$ & $11 / 03 / 12$ & Clayey & RB 855453 & $04 / 14 / 2010$ & $07 / 04 / 2012\left(2^{\text {nd }}\right.$ cut $)$ & 16.1 \\
\hline 2 & Tabapuã & $08 / 17 / 12$ & $11 / 05 / 12$ & Sandy clay & RB 835054 & $03 / 23 / 2008$ & $07 / 28 / 2012\left(5^{\text {th }}\right.$ cut $)$ & 8.1 \\
\hline 3 & Tabapuã & $08 / 17 / 12$ & $11 / 05 / 12$ & Sandy clay & RB 835054 & $03 / 23 / 2008$ & $07 / 28 / 2012\left(5^{\text {th }}\right.$ cut $)$ & 7.2 \\
\hline 4 & Itápolis & $08 / 17 / 12$ & $11 / 05 / 12$ & Sandy clay & RB 867515 & $11 / 26 / 2010$ & $07 / 18 / 2012\left(2^{\text {nd }}\right.$ cut $)$ & 8.0 \\
\hline 5 & Itápolis & $10 / 02 / 12$ & $11 / 29 / 12$ & Sandy clay & RB 867515 & $07 / 17 / 2008$ & $08 / 28 / 2012\left(4^{\text {th }}\right.$ cut $)$ & 13.6 \\
\hline
\end{tabular}


characterization of weeds and sugarcane, can be seen in Tables 3 and 4 .

On the day of the application of herbicides in the wet season, the number of emerged plants count (species of interest) was performed in two areas of $0.45 \mathrm{~m}^{2}$ each, randomly chosen within the usable area $\left(15.0 \mathrm{~m}^{2}\right)$ from the plot treatments 5, 6, 7, 9 and 11. Based on these values, the infestation of the areas was classified as low $\left(<4.9\right.$ plants $\left.\mathrm{m}^{-2}\right)$, average (from 5.0 to 10.0 plants $\mathrm{m}^{-2}$ ) and high $\left(>10.1\right.$ plants $\left.\mathrm{m}^{-2}\right)$.

At 30 and 120 days after application of herbicide in the wet season $\left(\mathrm{DAA}_{U}\right)$, out visual assessments of weed control were carried assigning scores from 0 to $100 \%$, where zero

Table 3 - Period, date, time, soil moisture, besides the weather conditions at the time of application of herbicides in each experiment

\begin{tabular}{|c|c|c|c|c|c|c|c|c|c|}
\hline \multirow{2}{*}{ Exp. } & \multicolumn{3}{|c|}{ Application } & \multicolumn{2}{|c|}{ Temperature $\left({ }^{\circ} \mathrm{C}\right)$} & \multirow{2}{*}{$\begin{array}{c}\text { Relative } \\
\text { humidity (\%) }\end{array}$} & \multirow{2}{*}{$\begin{array}{l}\text { Wind speed } \\
\left(\mathrm{km} \mathrm{h}^{-1}\right)\end{array}$} & \multirow{2}{*}{$\begin{array}{c}\text { Cloudiness } \\
(\%)\end{array}$} & \multirow{2}{*}{$\begin{array}{c}\text { Soil } \\
\text { moisture }\end{array}$} \\
\hline & Period & Date & Time & Air & Soil & & & & \\
\hline \multirow{2}{*}{1} & PRE & $07 / 11 / 12$ & $04: 35 \mathrm{pm}-05: 20 \mathrm{pm}$ & $27.3-23.4$ & $21.2-20.2$ & $47-63$ & $0.0-0.0$ & 0.0 & Dry \\
\hline & POST & $11 / 03 / 12$ & 08:20am-09:'00am & $25.0-25.2$ & $25.9-25.9$ & $69-73$ & $0.6-0.0$ & 0.0 & Wet \\
\hline \multirow{2}{*}{2} & PRE & $08 / 17 / 12$ & $04: 35 \mathrm{pm}-05: 23 \mathrm{pm}$ & $29.0-27.8$ & $24.1-23.8$ & $34-35$ & $6.5-2.5$ & $60-30$ & Dry \\
\hline & POST & $11 / 05 / 12$ & 10:40am-11:15am & $29.2-35.4$ & $25.8-26.2$ & $54-41$ & $2.0-0.0$ & 0.0 & Wet \\
\hline \multirow{2}{*}{3} & PRE & $08 / 17 / 12$ & 05:35pm-06:06pm & $27.6-20.5$ & $23.1-22.5$ & $36-49$ & $3.4-0.7$ & $30-0$ & Dry \\
\hline & POST & $11 / 05 / 12$ & 10:00am-10:30am & $28.1-29.1$ & $25.6-25.8$ & $60-54$ & $4.7-2.5$ & 0.0 & Wet \\
\hline \multirow{2}{*}{4} & PRE & $08 / 30 / 12$ & 08:35am-09:10am & $19.0-11.8$ & $20.6-21.5$ & $71-67$ & $2.3-4.9$ & 0.0 & Dry \\
\hline & POST & $11 / 03 / 12$ & 10:35am-11:10am & $30.6-34.0$ & $26.6-27.7$ & $63-51$ & $0.0-0.9$ & 0.0 & Wet \\
\hline \multirow{2}{*}{5} & PRE & $10 / 02 / 12$ & 08:20am-08:35am & $25.2-26.9$ & $21.3-22.1$ & $60-58$ & $1.8-1.9$ & 0.0 & Wet \\
\hline & POST & $11 / 29 / 12$ & 10:10am-10:30am & $35.1-37.8$ & $28.5-28.7$ & $60-54$ & $2.7-0.0$ & 0.0 & Wet \\
\hline
\end{tabular}

Table 4 - Characterization of weeds and sugarcane at the time of application of herbicides during the dry / semi-wet (pre-emergence - PRE - weed) and wet (post-emergence - POST - weed)

\begin{tabular}{|c|c|c|c|c|c|c|c|}
\hline \multirow{3}{*}{ Exp. } & \multicolumn{2}{|c|}{ PRE (dry / semi wet season) } & \multicolumn{5}{|c|}{ POST (Wet season) } \\
\hline & \multirow{2}{*}{ Sugarcane } & \multirow{2}{*}{ Weed } & \multirow{2}{*}{$\begin{array}{c}\text { Sugarcane } \\
\text { height }(\mathrm{cm})\end{array}$} & \multicolumn{4}{|c|}{ Weed } \\
\hline & & & & Specie & Infestation & Pl. $\mathrm{m}^{-2}$ & Height $(\mathrm{cm})$ \\
\hline \multirow{3}{*}{1} & \multirow{3}{*}{$\begin{array}{l}20 \% \text { sprouted } \\
\text { Spur stage }\end{array}$} & \multirow{3}{*}{ PRE } & \multirow{3}{*}{123.0} & Ipomoea hederifolia & Artificial $^{1 /}$ & $2.9^{\frac{2}{\prime}}$ & 47 to 147 \\
\hline & & & & Ipomoea quamoclit & Natural & 0.7 & 4 to 73 \\
\hline & & & & Merremia aegyptia & Artificial & 3.0 & 36 to 232 \\
\hline \multirow{2}{*}{2} & \multirow{2}{*}{$\begin{array}{l}50 \% \text { sprouted } \\
1 \text { to } 2 \text { leaves }\end{array}$} & \multirow{2}{*}{ PRE } & \multirow{2}{*}{80.0} & Ipomoea hederifolia & Natural & 19.4 & Cotyledon to 62 \\
\hline & & & & Ipomoea nil & Natural & 12.0 & 2 leaves at 78 \\
\hline \multirow{3}{*}{3} & \multirow{3}{*}{$\begin{array}{l}50 \% \text { sprouted } \\
1 \text { to } 2 \text { leaves }\end{array}$} & \multirow{3}{*}{ PRE } & \multirow{3}{*}{93.4} & Ipomoea hederifolia & Natural & 27.8 & Cotyledon at 83 \\
\hline & & & & Ipomoea nil & Natural & 4.2 & 4 leaves at 54 \\
\hline & & & & Ipomoea quamoclit & Natural & 3.2 & 4 leaves at 54 \\
\hline \multirow{4}{*}{4} & \multirow{4}{*}{$\begin{array}{l}80 \% \text { sprouted } \\
2 \text { to } 3 \text { leaves }\end{array}$} & \multirow{4}{*}{ PRE } & \multirow{4}{*}{110.0} & Ipomoea hederifolia & Artificial & 9.7 & Cotyledon at 82 \\
\hline & & & & Ipomoea nil & Natural & 8.8 & 2 to 3 leaves at 127 \\
\hline & & & & Ipomoea triloba & Natural & 5.1 & 4 leaves at 57 \\
\hline & & & & Merremia aegyptia & Artificial & 9.4 & 8 to 147 \\
\hline \multirow{3}{*}{5} & \multirow{3}{*}{$\begin{array}{l}70 \% \text { sprouted } \\
2 \text { to } 3 \text { leaves }\end{array}$} & \multirow{3}{*}{ PRE } & \multirow{3}{*}{118.0} & Ipomoea hederifolia & Artificial & 1.6 & 25 to 72.5 \\
\hline & & & & Ipomoea triloba & Natural & 2.5 & 10 to 146 \\
\hline & & & & Merremia aegyptia & Artificial & 3.8 & 9 to 167 \\
\hline
\end{tabular}

${ }^{1 /}$ Before the application of herbicides in dry or semi-wet season artificial infestation of plots $(3.0 \mathrm{~m} \times 14.0 \mathrm{~m})$ was performed by sowing 0.42 and $0.62 \mathrm{~g} \mathrm{~m}^{-2}$ of Ipomoea hederifolia and Merremia aegyptia seeds, respectively. ${ }^{2 /}$ Mean value obtained in two samples of $0.45 \mathrm{~m}^{2}$ each, randomly chosen in the usable area of plots of treatments 5, 6, 7, 9 and 11. 
is the absence of control and 100 the plant death. Control scores were established based on control kept with weeds throughout the experimental period (control 4).

Possible visual damage in sugarcane plants were evaluated at 30, 60, 90 and 120 DAA of herbicides, through the scale from 0 to $100 \%$, where zero represents the absence of visual injury and 100 the death of plant (SBCPD, 1995).

At the time of harvest, the counting of industrialized stalks of sugarcane was performed in each plot (in $15.0 \mathrm{~m}^{2}$, a line $\mathrm{x}$ $10.0 \mathrm{~m}$ long) and the collection of 20 of them, chosen in line sequentially, to quantify the production. Based on the total number of culms in $15.0 \mathrm{~m}^{2}$ and on the weight of 20 stems, production was estimated per hectare in experiments 3,4 and 5 . In other experiments (1 and 2 ) due to the sharp plants lodging, it was not possible to harvest.

The results obtained in each experiment were submitted to the F-test of analysis of variance, and treatments, when significant, were compared by Tukey test at $5 \%$ probability. The phytotoxicity scores were not subjected to statistical analysis.

\section{RESULTS AND DISCUSSION}

Five species of morning glory (Ipomoea hederifolia, Ipomoea nil, Ipomoea quamoclit, Ipomoea triloba and Merremia aegyptia) were evaluated in the experiments, which were classified into low infestation ( $<4.9$ plants $\left.\mathrm{m}^{-2}\right)$, average (from 5.0 to 10.0 plants $\mathrm{m}^{-2}$ ) and high $\left(>10.1\right.$ plants $\left.\mathrm{m}^{-2}\right)$. I. hederifolia occurred in $100 \%$ of the experiments, with low or high infestation; $I$. nil and $M$. aegyptia were evaluated in three experiments; and I. quamoclit and I. triloba in only two. The density of plants per $\mathrm{m}^{2}$ of each species morning glory is presented in Table 4.

To control I. hederifolia, at 30 days after herbicide application in the wet season $\left(\mathrm{DAA}_{U}\right)$, it was found that, regardless of the infestation level, there was no significant difference between the chemical treatments, with average scores of $97 \%$ (experiment 2 high infestation) to $100 \%$ (experiment 5 low infestation) (Table 5). Therefore, the herbicides applied during the dry and semiwet seasons did not differ from those applied in the wet season, up to $30 \mathrm{DAA}_{U}$. As also observed at $120 \mathrm{DAA}_{U}$, except for the experiment 1 (low infestation), in which the application of mesotrione alone differed from other herbicides and resulted in a lower percentage of control (Table 6). The average values at $120 \mathrm{DAA}_{U}$ ranged from $81 \%$ (experiment 3 - high infestation) to 99\% (experiment 5 - low infestation) (Table 5).

To I. nil, at $30 \mathrm{DAA}_{\mathrm{U}}$ only in the experiment 4 (average infestation) there was significant difference between treatments with herbicides, resulting in less control of scores with the application of mesotrione alone which did not differ from imazapic (Tables 6 and 7). For other experiments ( 2 and 3 - low and high infestation, respectively), chemical treatments did not differ. The same happened at $120 \mathrm{DAA}_{U}$ in three experiments in which there was no significant difference between the herbicides, regardless of the infestation level of $I$. nil in the areas. The mean of control of this species varies from 95\% (experiment 4 average infestation) to $98 \%$ (experiment 2 high infestation), at $120 \mathrm{DAA}_{U}$.

In both experiments in which I. quamoclit was evaluated (low level of infestation) chemical treatments did not differ in the two evaluation periods, with average control of 94.4\% (experiment 3 ) to $98.3 \%$ (experiment 1 ) at $120 \mathrm{DAA}_{\mathrm{U}}$ (Table 8).

To I. triloba there was no difference between the chemical treatments in both experiments in which this species occurred (low and medium infestation), in both evaluation periods (Table 8). The control average ranged from $91 \%$ (experiment 5 low infestation) to $94 \%$ (experiment 4 average infestation) at $120 \mathrm{DAA}_{U}$.

At $30 \mathrm{DAA}_{U}$, the herbicide treatments did not differ for the control of $M$. aegyptia, in the three experiments where this species was evaluated (low to medium infestation) (Table 9). As also observed at $120 \mathrm{DAA}_{U}$ in the experiments 4 and 5 . In the experiment 1 (low infestation) there was a lower percentage of control with the application of mesotrione alone, differing only from mesotrione + 
Table 5 - Results of F-Test of analysis of variance for percentage of Ipomoea hederifolia control in five experiments at 30 and 120 days after application (DAA) of post-emergence treatments in the sugarcane culture

\begin{tabular}{|c|c|c|c|c|c|c|c|c|c|c|c|}
\hline \multirow{4}{*}{$\begin{array}{c}\text { Font of } \\
\text { variation }\end{array}$} & \multirow{4}{*}{ G.L. } & \multicolumn{10}{|c|}{ Experiment } \\
\hline & & \multicolumn{2}{|c|}{1} & \multicolumn{2}{|c|}{2} & \multicolumn{2}{|c|}{3} & \multicolumn{2}{|c|}{4} & \multicolumn{2}{|c|}{5} \\
\hline & & \multicolumn{10}{|c|}{ Evaluation period (DAA) } \\
\hline & & 30 & 120 & 30 & 120 & 30 & 120 & 30 & 120 & 30 & 120 \\
\hline Treatments $^{\underline{1}}$ & 6 & $2.4^{\mathrm{ns}}$ & $7.0 * *$ & $1.1^{\mathrm{ns}}$ & $0.9^{\mathrm{ns}}$ & $0.8^{\mathrm{ns}}$ & $2.3^{\mathrm{ns}}$ & $1.6^{\mathrm{ns}}$ & $1.9^{\mathrm{ns}}$ & - & $0.9^{\mathrm{ns}}$ \\
\hline Block & 3 & $1.5^{\mathrm{ns}}$ & $2.0^{\mathrm{ns}}$ & $3.5^{\mathrm{ns}}$ & $4.8^{*}$ & $1.1^{\mathrm{ns}}$ & $13.6^{\mathrm{ns}}$ & $1.8^{\mathrm{ns}}$ & $2.4^{\mathrm{ns}}$ & - & $1.9^{\mathrm{ns}}$ \\
\hline \multicolumn{2}{|l|}{ CV $(\%)$} & 3.6 & 3.4 & 5.1 & 10.2 & 3.3 & 10.0 & 6.7 & 11.0 & - & 2.6 \\
\hline \multicolumn{2}{|c|}{ Mean ( $\%$ control $)$} & 98.8 & 97.9 & 96.6 & 86.6 & 98.4 & 80.7 & 95.9 & 92.1 & 100.00 & 99.2 \\
\hline
\end{tabular}

1/ Data from the control without application were not included in the statistical analysis. ** Significant at $1 \%$ probability by F-test of analysis of variance. ${ }^{\text {ns }}$ Not significant by F-test of analysis of variance.

Table 6 - Control percentage of Ipomoea hederifolia and Merremia aegyptia in experiment 1, at 120 days after application (DAA) of post-emergence treatments ${ }^{1 /}$ in the culture of sugarcane, and of Ipomoea nil in the experiment 4, 30 DAA, in addition to control without application

\begin{tabular}{|c|c|c|c|c|}
\hline \multirow{4}{*}{ Herbicide/Control } & \multirow{4}{*}{$\begin{array}{l}\text { Dosage } \\
\left(\mathrm{kg} \mathrm{ha}^{-1}\right)\end{array}$} & I. hederifolia & M. aegyptia & I. nil \\
\hline & & \multicolumn{3}{|c|}{ Experiment } \\
\hline & & \multicolumn{2}{|c|}{1} & 4 \\
\hline & & \multicolumn{3}{|c|}{ Control (\%) } \\
\hline 1- Sulfentrazone & 0.9 & $100.0 \mathrm{a}^{2 /}$ & $91.2 \mathrm{ab}$ & $100.0 \mathrm{a}$ \\
\hline 2- Amicarbazone & 1.4 & $98.1 \mathrm{a}$ & $96.2 \mathrm{ab}$ & $100.0 \mathrm{a}$ \\
\hline 3- Imazapic & 0.147 & $100.0 \mathrm{a}$ & $57.5 \mathrm{ab}$ & $93.1 \mathrm{ab}$ \\
\hline $\begin{array}{r}\text { 4- Hexazinone } \\
\text { Tebuthiuron }\end{array}$ & $\begin{array}{l}0.325 \\
0.75\end{array}$ & $100.0 \mathrm{a}$ & $77.5 \mathrm{ab}$ & $100.0 \mathrm{a}$ \\
\hline 5- Mesotrione $\mathrm{e}^{-3 /}$ & 0.192 & $88.1 \mathrm{~b}$ & $37.5 \mathrm{~b}$ & $86.2 \mathrm{~b}$ \\
\hline $\begin{array}{l}\text { 6- Mesotrione } \\
\text { Atrazine }\end{array}$ & $\begin{array}{l}0.12 \\
1.5\end{array}$ & $100.0 \mathrm{a}$ & $98.1 \mathrm{a}$ & $98.8 \mathrm{a}$ \\
\hline $\begin{array}{l}\text { 7- Mesotrione } \\
\text { Diuron+hexazinone }\end{array}$ & $\begin{array}{l}0.12 \\
0.491 \\
0.139\end{array}$ & $99.4 \mathrm{a}$ & $94.4 \mathrm{ab}$ & $100.0 \mathrm{a}$ \\
\hline \multicolumn{2}{|l|}{ 8- Control infested in the wet season ${ }^{4 /}$} & 0.0 & 0.0 & 0.0 \\
\hline \multicolumn{2}{|l|}{ 9- Control infested in the dry season } & 100.0 & 100.0 & 100.0 \\
\hline \multicolumn{2}{|l|}{ 10- Control without weeds } & 100.0 & 100.0 & 100.0 \\
\hline \multicolumn{2}{|l|}{ 11- Control infested throughout the cycle } & 0.0 & 0.0 & 0.0 \\
\hline DMS & & 7.8 & 59.8 & 11.4 \\
\hline
\end{tabular}

${ }^{1 /}$ Treatments 5, 6 and 7; at $120 \mathrm{DAA}_{\mathrm{POST}}$ corresponds to 231,202, 202, 188 and 184 days after application of herbicides PRE (treatments $1,2,3$ and 4), respectively for experiment $1,2,3,4$ and $5 .{ }^{2}$ Means followed by the same letter in the column do not differ significantly by Tukey test at $5 \%$ probability. ${ }^{3 /}$ All syrup with mesotrione were added mineral oil at $0.5 \% \mathrm{v} \mathrm{v}^{-1} . .^{4 /}$ Data from control without application were not included in the statistical analysis.

atrazine (Table 6). The smallest control scores of $M$. aegyptia with mesotrione alone occurred due to the regrowth of the treated plants, justified by their high size at the time of herbicide application. The control average of this species at $120 \mathrm{DAA}_{U}$ varied from $79 \%$ (experiment 1 - low infestation) to 95\% (experiment 5 - low infestation) (Table 9).
Herbicides sprayed in water restriction in the culture of sugarcane must present specific physical and chemical characteristics such as high solubility in water and low or moderate adsorption to soil, as well as losses by volatilization and negligible photobleaching. The stability of the molecule is more limiting in mechanized harvesting conditions with the 
Table 7 - Results of F-Test of analysis of variance for control percentage of Ipomoea nil in three experiments, at 30 and 120 days after application (DAA) of the post-emergence treatments ${ }^{\underline{1}}$ in the culture of sugarcane

\begin{tabular}{|c|c|c|c|c|c|c|c|}
\hline \multirow{4}{*}{ Font of variation } & \multirow{4}{*}{ GL } & \multicolumn{6}{|c|}{ Experiment } \\
\hline & & \multicolumn{2}{|c|}{2} & \multicolumn{2}{|c|}{3} & \multicolumn{2}{|c|}{4} \\
\hline & & \multicolumn{6}{|c|}{ Evaluation period (DAA) } \\
\hline & & 30 & 120 & 30 & 120 & 30 & 120 \\
\hline Treatments $^{\underline{1 /}}$ & 6 & $1.0^{\mathrm{ns}}$ & $1.0^{\mathrm{ns}}$ & $1.0^{\mathrm{ns}}$ & $1.4^{\mathrm{ns}}$ & $4.7 * *$ & $1.8^{\mathrm{ns}}$ \\
\hline Block & 3 & $0.7^{\mathrm{ns}}$ & $0.5^{\mathrm{ns}}$ & $1.9^{\mathrm{ns}}$ & $1.6^{\mathrm{ns}}$ & $0.3^{\mathrm{ns}}$ & $0.1^{\mathrm{ns}}$ \\
\hline \multicolumn{2}{|l|}{$\mathrm{CV}(\%)$} & 3.5 & 4.7 & 2.4 & 4.7 & 5.1 & 7.4 \\
\hline \multicolumn{2}{|l|}{ Mean (\% control) } & 99.0 & 98.3 & 99.4 & 98.2 & 96.9 & 95.4 \\
\hline
\end{tabular}

1/ Data from control without application were not included in the statistical analysis. ${ }^{* *}$ Significant at $1 \%$ probability by F-test of analysis of variance. ${ }^{\text {ns }}$ Not significant by F-test of analysis of variance.

Table 8 - Results of F-Test of analysis of variance for control percentage of Ipomoea quamoclit and Ipomoea triloba in two experiments at 30 and 120 days after application (DAA) of the post-emergence treatments ${ }^{1 /}$ in the culture of sugarcane

\begin{tabular}{|c|c|c|c|c|c|c|c|c|c|}
\hline \multirow{5}{*}{ Font of variation } & \multirow{5}{*}{ GL } & \multicolumn{4}{|c|}{ I. quamoclit } & \multicolumn{4}{|c|}{ I. triloba } \\
\hline & & \multicolumn{8}{|c|}{ Experiment } \\
\hline & & \multicolumn{2}{|c|}{1} & \multicolumn{2}{|c|}{3} & \multicolumn{2}{|c|}{4} & \multicolumn{2}{|c|}{5} \\
\hline & & \multicolumn{8}{|c|}{ Evaluation period (DAA) } \\
\hline & & 30 & 120 & 30 & 120 & 30 & 120 & 30 & 120 \\
\hline Treatments $^{\underline{1}}$ & 6 & $1.0^{\mathrm{ns}}$ & $0.7^{\mathrm{ns}}$ & $1.0^{\mathrm{ns}}$ & $0.2^{\mathrm{ns}}$ & $0.7^{\mathrm{ns}}$ & $1.4^{\mathrm{ns}}$ & $0.5^{\mathrm{ns}}$ & $1.0^{\mathrm{ns}}$ \\
\hline Block & 3 & $1.0^{\mathrm{ns}}$ & $0.6^{\mathrm{ns}}$ & $1.0^{\mathrm{ns}}$ & $3.9^{\mathrm{ns}}$ & $0.6^{\mathrm{ns}}$ & $1.4^{\mathrm{ns}}$ & $0.5^{\mathrm{ns}}$ & $1.2^{\mathrm{ns}}$ \\
\hline \multicolumn{2}{|l|}{$\mathrm{CV}(\%)$} & 0.2 & 5.7 & 2.4 & 8.4 & 5.3 & 6.5 & 2.0 & 7.3 \\
\hline \multicolumn{2}{|l|}{ Mean (\% control) } & 99.9 & 98.3 & 99.6 & 94.4 & 97.9 & 94.5 & 99.3 & 91.3 \\
\hline
\end{tabular}

$1 /$ Data from control without application were not included in the statistical analysis. ${ }^{\text {ns }}$ Not significant by F-test of analysis of variance.

Table 9 - Results of F-Test of analysis of variance for control percentage of Merremia aegyptia in three experiments at 30 and 120 days after application (DAA) of the post-emergence treatments ${ }^{1 /}$ in the culture of sugarcane

\begin{tabular}{|c|c|c|c|c|c|c|c|}
\hline \multirow{4}{*}{ Font of variation } & \multirow{4}{*}{ G.L. } & \multicolumn{6}{|c|}{ Experiment } \\
\hline & & \multicolumn{2}{|c|}{1} & \multicolumn{2}{|c|}{4} & \multicolumn{2}{|c|}{5} \\
\hline & & \multicolumn{6}{|c|}{ Evaluation period (DAA) } \\
\hline & & 30 & 120 & 30 & 120 & 30 & 120 \\
\hline Treatments $^{\underline{1}}$ & 6 & $2.6^{\mathrm{ns}}$ & $3.3^{*}$ & $2.4^{\mathrm{ns}}$ & $2.3^{\mathrm{ns}}$ & $1.2^{\mathrm{ns}}$ & $1.7^{\mathrm{ns}}$ \\
\hline Block & 3 & $1.7^{\mathrm{ns}}$ & $1.5^{\mathrm{ns}}$ & $1.6^{\mathrm{ns}}$ & $0.9^{\mathrm{ns}}$ & $1.1^{\mathrm{ns}}$ & $0.9^{\mathrm{ns}}$ \\
\hline \multicolumn{2}{|l|}{$\mathrm{CV}(\%)$} & 9.5 & 32.4 & 13.8 & 15.7 & 9.9 & 9.7 \\
\hline \multicolumn{2}{|l|}{ Mean (\% control) } & 93.7 & 78.9 & 94.0 & 91.1 & 97.1 & 94.6 \\
\hline
\end{tabular}

$1 /$ Data from control without application were not included in the statistical analysis. * Significant at $1 \%$ probability by F-test of analysis of variance. ${ }^{\mathrm{ns}}$ Not significant by F-test of analysis of variance.

maintenance of straw on the ground (green cane) as the herbicide will be retained in crop residues and only after the occurrence of rain or irrigation, in sufficient volume, it reaches the soil. In this regard, the herbicides imazapic, amicarbazone and tebuthiuron have too high solubility in water; hexazinone extremely high solubility; and sulfentrazone, average solubility. They are weakly adsorbed to soil and little (imazapic, hexazinone and tebuthiuron) or involatile (sulfentrazone and amicarbazone) (Rodrigues \& Almeida, 2011). 
These parameters make these products suitable for use in the cane fields in the drier times of the year.

In this dry condition, herbicidal will be retained to the solid fraction of the soil and will not be available in the syrup for absorption by the seedlings. Concomitantly, the weed seeds did not start the germination process, and sugarcane plants will show slower growth.
Therefore, the dynamics of herbicides in soil is directly regulated by soil moisture. Thus, the products sprayed on sugarcane in dry or semi-wet time only have biological activity in the soil with moisture restoration (rainfall). That happens effectively from the months of October or November in the São Paulo sugarcane fields. In experiment 1 , the first rain occurred about 60 days after herbicide application in the dry season (Figure 1). In

(A)

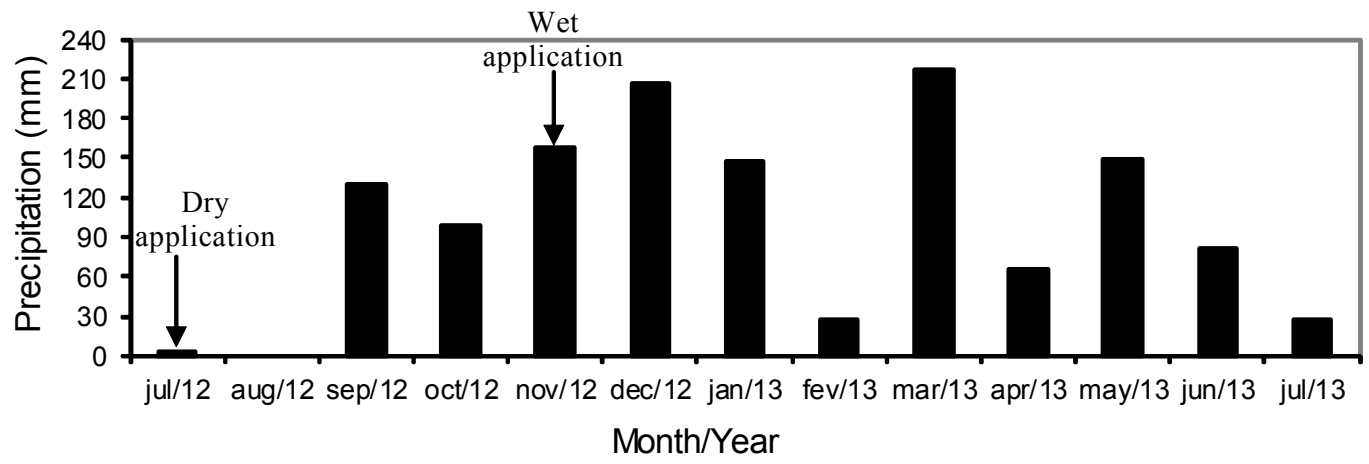

(B)

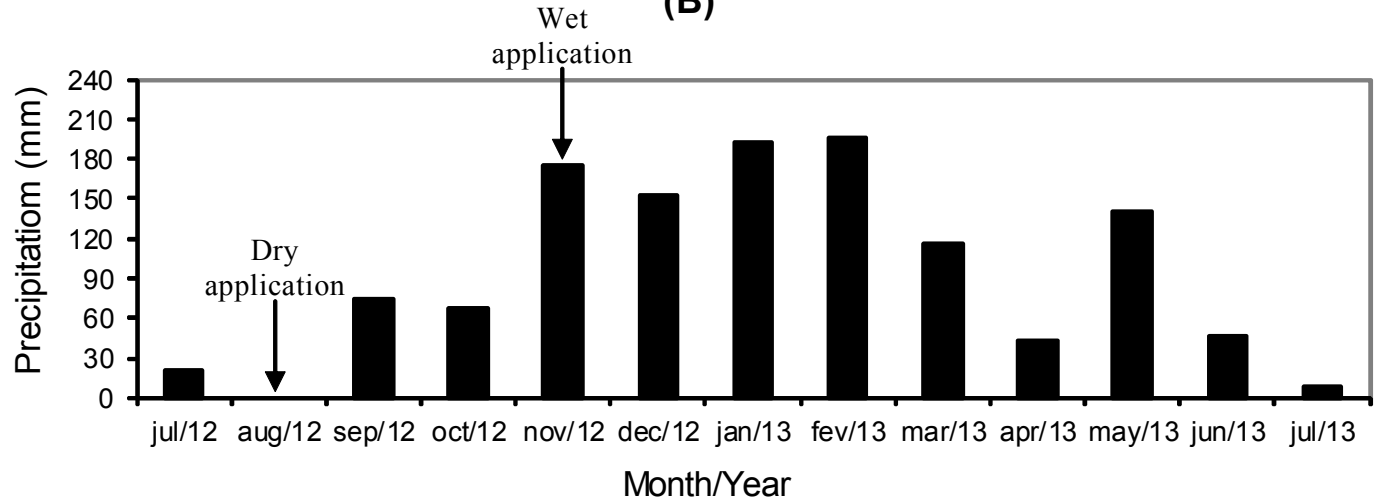

(C)

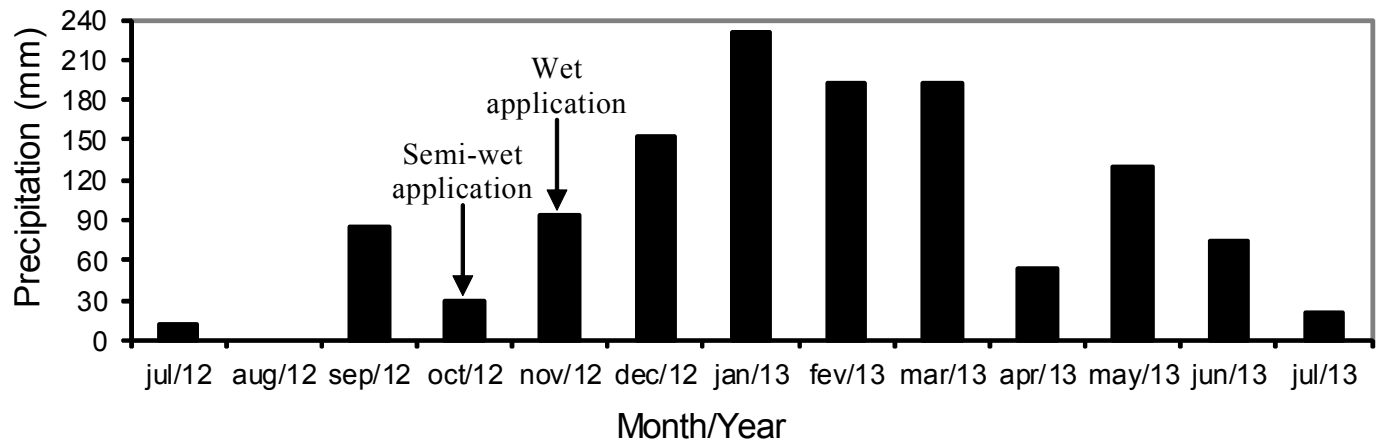

Figure 1 - Monthly total precipitation amounts recorded during the months of July 2012 to July 2013 in the first (A); second and third (B); fourth and fifth experiments (C). 
experiments 2 and 3 , the same thing happened about 30 days after application. In experiments 4 and 5, the moisture condition in the period before and after the application was slightly better. However, in the five experiments soil moisture was only resumed from November, based on monthly accumulated volume.

The herbicides sulfentrazone and amicarbazone are the most used in sugarcane, in the dry and semi-wet times, for morning glory control, which is justified by the susceptibility of plants and tolerance of the product to adverse environmental conditions such as drought and long period on sugarcane straw without loss in biological activity. In other studies, among the evaluated herbicides, sulfentrazone was minimally affected by environmental conditions and by the applied dosages (Viator et al., 2002; Jones \& Griffin, 2008) and remained on sugarcane straw for up to 90 days without losing the potential on controlling I. hederifolia and I. quamoclit after the occurrence of rain (Correia et al., 2013). However, depending on the infestation level (seed bank in the soil), the species and spray dosage, the use of herbicides in the sugarcane fields in the dry season is not effective, requiring complementation with other herbicides in the wet season, due to the new plant emergency flows in the area (Correia et al., 2010). In post-emergence, in the wet season, the herbicide mesotrione in combination with other herbicides (usually atrazine or diuron + hexazinone) It is most commonly used to control morning glory, either by tractor or aerial application.

In this study, in the dosages, and soil and weather conditions of the experiment, the herbicides sulfentrazone, amicarbazone, imazapic and tebuthiuron + hexazinone, sprayed during the dry and semi-wet remained in sufficient concentrations in the soil for controlling the species of morning glory until the canopy closure of sugarcane plants, that happened from 60 to $90 \mathrm{DAA}_{U}$, with similar results to the herbicide mesotrione, alone and in mixture with atrazine or diuron + hexazinone, except for controlling $M$. aegyptia by herbicides imazapic and mesotrione alone, in some situations.

As to the phytotoxic effects of herbicides on the crop (Table 10), at 30 DAA, in experiment 1 , herbicides tested did not cause visual damage to sugarcane plants. However, the following evaluation (at $60 \mathrm{DAA}$ ) found mild poisoning of plants, promoted by herbicides sulfentrazone, imazapic and hexazinone + tebuthiuron, with scores lower than $4.4 \%$. At 90 DAA, the symptoms were not observed result of the plants recovery.

In experiment 2 , at $30 \mathrm{DAA}$, herbicides sulfentrazone, amicarbazone and imazapic caused mild phytotoxicity $(<5 \%)$ to the cane, while mesotrione + (diuron + hexazinone) resulted in higher visible damage $(>20 \%)$. In experiment 3 only this treatment [mesotrione + (diuron + hexazinone)] caused visual injuries $(21 \%)$ to sugarcane plants. At 60 DAA, in these two experiments, only the plants sprayed with [mesotrione + (diuron + hexazinone)] presented phytotoxicity symptoms that were not observed at 90 DAA, due to the recovery of plants.

In experiments 4 and 5 , none of the wet season treatments was toxic for sugarcane. At 30 DAA, the herbicide imazapic caused most visual damage to the plants of these experiments, with scores from $6 \%$ to $12 \%$. However, at 60 DAA, visual symptoms of phytotoxicity were not observed anymore.

As for the culms production, in experiments 3 and 5 there was no significant difference between treatments, including the control kept infested throughout the trial period (Table 11). However, for the experiment 4 , in this control plants of sugarcane had lower production, not differing from treatments sulfentrazone, amicarbazone and control infested in the wet season.

In experiment 4 , when comparing the control without weed with infested control in the wet season, dry season and throughout the trial period, the losses were $1 \%, 18 \%$ and $35 \%$, respectively. These results show that the weeds present in the culture of sugarcane in the wet season had higher competition than the infestation occurred in the dry season.

Although the amicarbazone have not caused visual injury to the sugarcane plants in experiments 3,4 and 5 , this herbicide most affected the production of cane stalks, with significant losses of $20.2 \%$ in experiment 2 . As the amicarbazone was extremely effective in the management of weeds evaluated, it 
Table 10 - Phytointoxication scores ${ }^{1 /}$ obtained at 30 and 60 days after application of herbicides PRE (treatments 1,2,3 and 4) and POST (treatments 5, 6 and 7) in the culture of sugarcane

\begin{tabular}{|c|c|c|c|c|c|c|c|c|c|c|c|}
\hline \multirow{4}{*}{ Herbicide control } & \multirow{4}{*}{$\begin{array}{l}\text { Dosage } \\
\left(\mathrm{kg} \mathrm{ha}^{-1}\right)\end{array}$} & \multicolumn{10}{|c|}{ Experiment } \\
\hline & & \multicolumn{2}{|c|}{1} & \multicolumn{2}{|c|}{2} & \multicolumn{2}{|c|}{3} & \multicolumn{2}{|c|}{4} & \multicolumn{2}{|c|}{5} \\
\hline & & \multicolumn{10}{|c|}{ Phytointoxication (\%) - DAA } \\
\hline & & 30 & 60 & 30 & 60 & 30 & 60 & 30 & 60 & 30 & 60 \\
\hline 1- Sulfentrazone & 0.9 & 0.0 & 1.2 & 3.3 & 0.0 & 0.0 & 0.0 & 1.2 & 0.0 & 0.0 & 0.0 \\
\hline 2- Amicarbazone & 1.4 & 0.0 & 0.0 & 5.0 & 0.0 & 0.0 & 0.0 & 0.0 & 0.0 & 0.0 & 0.0 \\
\hline 3- Imazapic & 0.147 & 0.0 & 4.4 & 3.3 & 0.0 & 0.0 & 0.0 & 6.2 & 0.0 & 12.5 & 0.0 \\
\hline $\begin{array}{l}\text { 4- Hexazinone } \\
\text { Tebuthiuron }\end{array}$ & $\begin{array}{l}0.325 \\
0.75\end{array}$ & 0.0 & 1.9 & 0.0 & 0.0 & 0.0 & 0.0 & 0.0 & 0.0 & 0.0 & 0.0 \\
\hline 5- Mesotrione $e^{2 /}$ & 0.192 & 0.0 & 0.0 & 0.0 & 0.0 & 0.0 & 0.0 & 0.0 & 0.0 & 0.0 & 0.0 \\
\hline $\begin{array}{l}\text { 6- Mesotrione } \\
\text { Atrazine }\end{array}$ & $\begin{array}{l}0.12 \\
1.5\end{array}$ & 0.0 & 0.0 & 0.0 & 0.0 & 0.0 & 0.0 & 0.0 & 0.0 & 0.0 & 0.0 \\
\hline $\begin{array}{l}\text { 7- Mesotrione } \\
\text { Diuron+hexazinone }\end{array}$ & $\begin{array}{l}0.12 \\
0.491 \\
0.139\end{array}$ & 0.0 & 0.0 & 21.7 & 11.7 & 21.2 & 5.0 & 0.0 & 0.0 & 0.0 & 0.0 \\
\hline \multicolumn{2}{|c|}{ 8- Control infested in the wet season } & 0.0 & 0.0 & 0.0 & 0.0 & 0.0 & 0.0 & 0.0 & 0.0 & 0.0 & 0.0 \\
\hline \multicolumn{2}{|c|}{ 9- Control infested in the dry season } & 0.0 & 0.0 & 0.0 & 0.0 & 0.0 & 0.0 & 0.0 & 0.0 & 0.0 & 0.0 \\
\hline \multicolumn{2}{|c|}{ 10- Control without weeds } & 0.0 & 0.0 & 0.0 & 0.0 & 0.0 & 0.0 & 0.0 & 0.0 & 0.0 & 0.0 \\
\hline \multicolumn{2}{|c|}{ 11- Control infested throughout the cycle } & 0.0 & 0.0 & 0.0 & 0.0 & 0.0 & 0.0 & 0.0 & 0.0 & 0.0 & 0.0 \\
\hline
\end{tabular}

$1 /$ Data were not subjected to statistical analysis. ${ }^{2 /}$ All syrup with mesotrione were added mineral oil at $0.5 \% \mathrm{v} \mathrm{v}^{-1}$.

Table 11 - Production $\left(\mathrm{t} \mathrm{ha}^{-1}\right)$ of sugarcane culms at 353, 346 and 317 days after the cut in 2012 respectively for the experiments 1 , 2 and 5

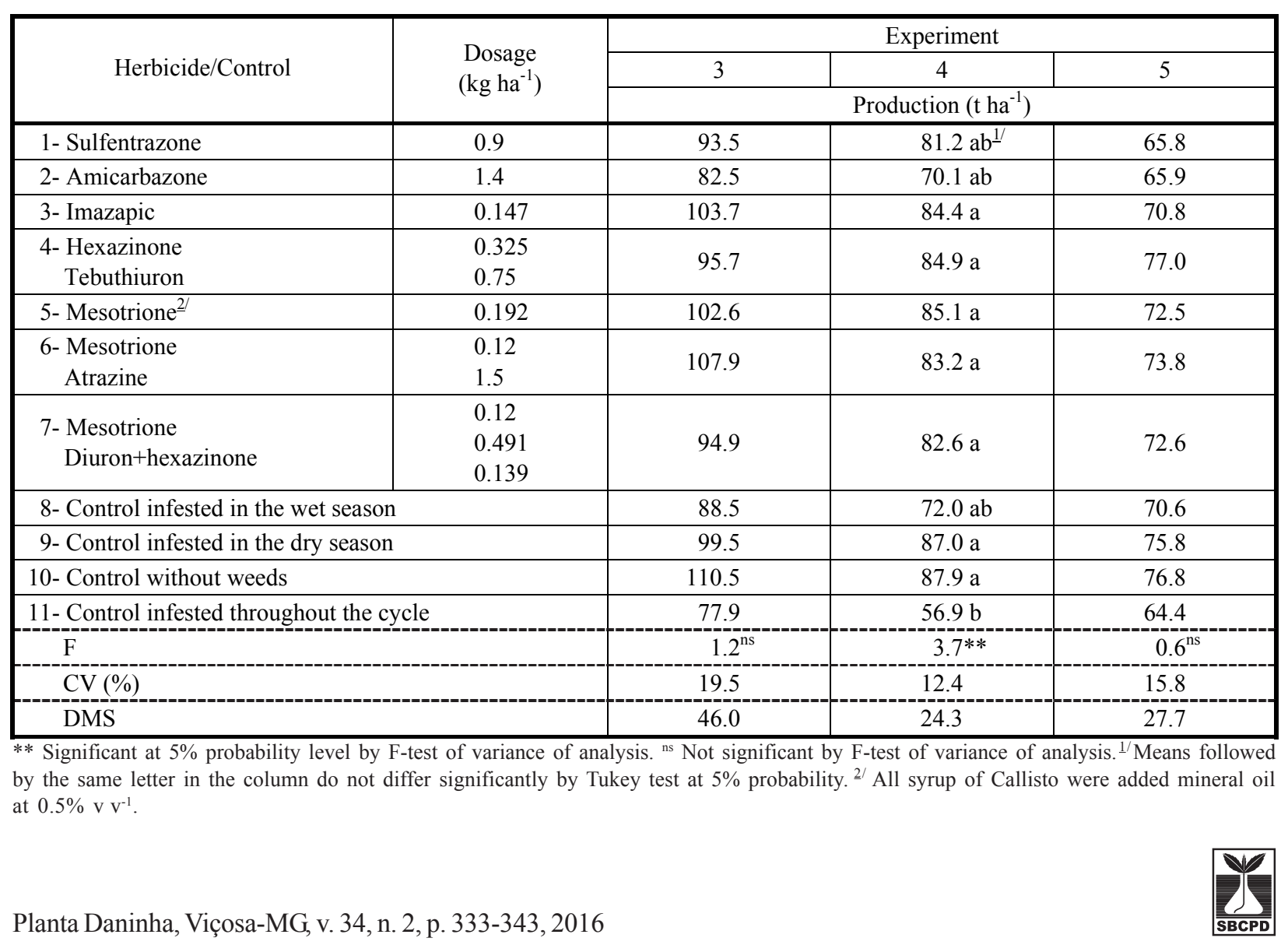


is believed that the negative impact on productivity of sugarcane was due solely to the phytotoxic action of the product.

In this study, the differential response of herbicides between experiments can be explained by genetic material (cane farming) planted in the experimental areas. The cultivar of sugarcane experiments 2 and 3 was RB835054; experiments 4 and 5, RB867515; and experiment 1, RB855453. Araldi et al. (2011) found differential susceptibility of sugarcane cultivars PO8862, SP803280 and RB835486 to herbicide amicarbazone, justified, possibly by differential absorption of the herbicide between cultivars. Moreover, regardless of genetic material, the mesotrione and mesotrione + atrazine treatments did not cause visual symptoms of phytotoxicity on sugarcane. The availability of water in the soil, especially for herbicides applied during the dry and semi-wet seasons, can also affect their phytotoxic action.

Based on the results, it is concluded that, regardless of the time of application, all herbicides resulted in similar control of I. hederifolia, Ipomoea nil, I. quamoclit and I. triloba. The herbicides imazapic (sprayed pre-emergence in the dry and semi-wet seasons) and mesotrione alone (applied postemergence in the wet season), at the tested doses, promoted a lower control percentage of Merremia aegyptia. Imazapic and the mixture mesotrione + (diuron + hexazinone) caused greater visual phytointoxication to sugarcane. However, most production loss was caused by amicarbazone. Mesotrione alone and mixed with atrazine does not cause visual damage to sugarcane plants.

\section{LITERATURE CITED}

ARALDI, R. et al. Avaliação da intoxicação de cultivares de cana-de-açúcar e I. grandifolia ao amicarbazone. Planta Daninha, v. 29, n. 4, p. 869-875, 2011.

BHULLAR, M. S. et al. Control of morningglories (Ipomoea spp.) in Sugarcane (Saccharum spp.) Weed Technol., v. 26, n. 1, p. 77-82, 2012.

CORREIA, N. M.; KRONKA JR., B. Controle químico de plantas dos gêneros Ipomoea e Merremia em cana-soca. Planta Daninha, v. 28, p.1143-1152, 2010. (Número Especial)
CORREIA, N. M.; CAMILO, E. H.; SANTOS, E. A. Sulfentrazone efficiency on Ipomoea hederifolia and Ipomoea quamoclit as influenced by rain and sugarcane straw. Planta Daninha, v. 31, n. 1, p. 165-174, 2013.

FOOD AND AGRICULTURE ORGANIZATION OF THE UNITED NATIONS - FAO. Food and agricultural production crops: sugarcane 2013. Rome: Food and Agriculture Organization of the United Nations. <http:// faostat3.fao.org/browse/Q/QC/S>. Assessed: January 13, 2016.

GIORI, F. G.; TORNISIELO, V. L.; REGITANO, F. B. The role of sugarcane residues in the sorption and leaching of herbicides in two tropical soils. Water Air Soil Pollut., v. 225, n. 1, p. 2-9, 2014.

IBGE. Indicadores IBGE - produção agrícola 2015. Disponível em: <ftp://ftp.ibge.gov.br/Producao_Agricola/ Levantamento_Sistematico_da_Producao_Agricola_\%5Bmensal\%5D/ Comentarios/lspa_201512comentarios.pdf $>$. Acesso em: 13 jan. 2016.

JONES, C. A.; GRIFFIN, J. L. Residual red morning-glory (Ipomoea Coccinea) control with foliar- and soil-applied herbicides. Weed Technol., v. 22, n. 3, p. 402-407, 2008.

JONES, C. A.; GRIFFIN, J. L. Red morning-glory (Ipomoea coccinea) control and competition in sugarcane. J. Am. Soc. Sugar Cane Technol., v. 29, n. 1, p. 25-53, 2009.

MERSIE, W. et al. Atrazine and metolachlor sorption to switchgrass residues. Comm. Soil Sci. Plant Anal., v. 37, n. 3-4, p. 465-472, 2006.

RODRIGUES, B. N. Influência da cobertura morta no comportamento dos herbicidas imazaquin e clomazone. Planta Daninha, v. 11, n. 1, p. 21-28, 1993.

RODRIGUES, B. N.; ALMEIDA, F. L. S. Guia de herbicidas. 6.ed. Londrina: Edição dos Autores, 2011. 697 p.

SELIM, H. M.; NAQUIN, B. J. Retention of metribuzin by sugarcane residue: adsorption-desorption and miscible displacement experiments. Soil Sci., v. 176, n. 10, p. 520-526, 2011.

SELIM, H. M.; NAQUIN, B. J.; LIAO, L. Adsorption and desorption of atrazine retention by sugarcane residue and soils. Soil Sci., v. 177, n. 5, p. 332-337, 2012.

SOCIEDADE BRASILEIRA DA CIÊNCIA DAS PLANTAS DANINHAS - SBCPD. Procedimentos para instalação, avaliação e análise de experimentos com herbicidas. Londrina: $1995.42 \mathrm{p}$.

VIATOR, B. J.; GRIFFIN, J. L; ELLIS, J. M. Red morningglory (Ipomoea coccinea) control with sulfentrazone and azafeniden applied at layby in sugarcane (Saccharum spp.). Weed Technol., v. 16, n. 1, p. 142-148, 2002. 